Annals of Plant Sciences

ISSN: 2287-688X

OPEN ACCESS

www.annalsofplantsciences.com

\title{
Salinity tolerance at germination of some main cultivated cowpea (Vigna unguiculata) genotypes from Western Cameroon
}

\section{Ebeny Leonny Tsague, Eric Bertrand Kouam*, Christopher Mubeteneh Tankou}

Genetics and Plant Biotechnology Laboratory, Department of Crop Sciences, Faculty of Agronomy and Agricultural Sciences, University of Dschang, Dschang, Cameroon.

Received: 2017-04-14; Accepted: 2017-05-27

\begin{abstract}
This study investigates the effect of salt $(\mathrm{NaCl})$ on the germination of seeds of 10 genotypes of cowpea (Vigna unguiculata). The experiment carried out on petri dishes was done using a completely randomized design comprising three replications. The germination of the cultivars was studied using distilled water as control and under osmotic potentials of 50,100,150 and $200 \mathrm{mM} \mathrm{NaCl}$. The results indicated that the Mean Germination Time (MGT), Time to $50 \%$ Germination $\left(\mathrm{T}_{50}\right)$, Germination Index (GI), Coefficient of Velocity of Germination (CVG), and Germination Percentage (GP), varied between 2.33 and 5.51 days; 2.83 and 14.87 days; 16.66 and 1.63; 0.53 and 0.11; 87.11 and $27.98 \%$ respectively. The variables GI, CVG and GP tended to decrease with increasing $\mathrm{NaCl}$ concentration while MGT and $T_{50}$ tended to increase with increasing salt concentrations. For all the germination variables, significant differences at 0.001 probability levels were found among salinity treatments, cowpea genotypes and their interaction. Four genotypes (KEB-CP118, OU59A, OU100 and ICV12) were tolerant to salt stress and performed well under salinity conditions. Four other genotypes were found to be moderately tolerant (ET11, NO1036, MTA22 and KEBCP009) and two genotypes (KEB-CP098 and NO193) were susceptible to salt stress and were most affected by salinity. At 0.001 probability level, positive correlations were observed between GP and GI ( $r=0.792)$; GP and CVG $(\mathrm{r}=0.774)$; GI and CVG $(\mathrm{r}=0.955)$ and negative correlations were observed between GP and $\mathrm{T}_{50}(\mathrm{r}=-0.845)$; GI and MGT $(\mathrm{r}=-0.894) ; \mathrm{CVG}$ and MGT $(\mathrm{r}=-0.895)$.
\end{abstract}

Keywords: Cameroon; Correlation; Germination; NaCl; Salinity tolerance; Vigna unguiculata

\section{Introduction}

Cowpea (Vigna unguiculata, (L.) Walp.) is a tropical leguminous plant species belonging to the Fabaceae family. The importance of this crop species in the Sub-Saharan regions cannot be overemphasized. Dry or fresh seeds contain $23-32 \%$ of protein and $64 \%$ of carbohydrate; the immature pods and leaves are used for human and animal consumption (Mahamadou et al., 2013). In addition, hay from cowpea is used for animal feeding during the dry season (Chinma et al., 2008). Cowpea appear then as a valuable source of income for farmers and grain traders in many African countries (Langyintuo et al., 2003; Timko et al., 2007). The market value in Sub-Saharan Africa is estimated at US\$ 662 / ton (Akibode, 2011). Cowpea production in SubSaharan Africa amounts to be 4.93 million tons of dry seed per year on 11.03 million ha and making an average yield of 0.45 ton / ha (Akibode, 2011). African production accounts for more than $70 \%$ of the world production and occupies $80 \%$ of the world's surface area for cowpea (Tengomo, 2011).

Salinity is one of the main constraints for agricultural productivity affecting almost 80 million hectares of arable lands worldwide (Yamaguchi and Blumwald, 2005). A soil is considered salty when the electrical conductivity is greater or equal to 4

*Corresponding Author:

Dr. Eric Bertrand Kouam,

Genetics and Plant Biotechnology Laboratory,

Department of Crop Sciences,

Faculty of Agronomy and Agricultural Sciences,

University of Dschang, PO Box 222 Dschang, Cameroon.

E-mail: ericbkouam@yahoo.com
$\mathrm{dS} \cdot \mathrm{m}-1$, making approximately $40 \mathrm{mM} \mathrm{NaCl}$ (Munns and Tester, 2008). Salt stress is induced by a wide range of dissolved salts, but $\mathrm{NaCl}$ is the most widespread one (Munns and Tester, 2008; Rengasamy, 2002). To enhance understanding of the mechanisms of tolerance in high salinity conditions, several studies have been carried out during the last three decades on plants collected worldwide. These investigations led to the conclusions that saline soils present unfavorable conditions for seed germination, plant growth and production (Mahamadou et al., 2013). Irrigation induces accumulation of salt at soil surface that negatively affect seed germination, plant vegetative development and productivity (Dantas et al., 2007; Tawfik, 2008). At some worst cases, salinity may cause plant death (Dantas et al., 2007; Tawfik, 2008). Salinity reduces the ability of plants to utilize water and causes a reduction in growth, as well as changes in plant metabolic processes (Munns, 1993, 2002). The impact of the salt will depend on the plant species, salinity levels, and the ionic composition (Yadav et al., 2010). According to Asana and Kale (1965) and Maas and Hoffman (1977), germination aptitude of seeds under salinity stress will differ from one crop to another and significant variation can be observed among 
different genotypes of the same crop as well. It appears important to identify the sensitivity and acceptance level of a variety or a genotype at germination stage for successful crop production in a saline milieu. Therefore, this study was undertaken to identify the salt-tolerance of some cowpea genotypes at germination level.

\section{Materials and Methods}

Plant materials

Plant materials were cowpea seeds of ten accessions: Eight from Cameroon (MTA22, KEBCP009, KEB-CP098, KEB-CP118, NO193, NO1036, OU59A, OU100) one from Kenya (ICV12) and one from Ethiopia (ET11). The study was conducted under controlled environmental conditions in the laboratory of genetics at the Faculty of Agronomy and Agricultural Sciences of the University of Dschang in Cameroon during April and May 2016.

\section{$\mathrm{NaCl}$ Solutions and seed treatments}

Healthy and uniform cowpea seeds of each accession were surface-sterilized with $7 \%$ sodium hypochlorite $(\mathrm{NaOCl})$ for $20 \mathrm{~min}$ (Sauer and Burroughs, 1986) and washed twice with distilled water for $10 \mathrm{~min}$. Seeds were then germinated in 90 mm diameter sterilized Petri dishes. All Petri dishes were washed with tap water and rinsed with distilled water. $\mathrm{NaCl}$ solutions were prepared at a concentration of 0.0 (Control), 50, 100, 150 and $200 \mathrm{mM}$ (Saline $(\mathrm{NaCl})$ conditions). The Petri dishes were arranged in a completely randomized block design with three replications. A total of 30 seeds were placed in each Petri dish on double-layer Whatman paper $\mathrm{N}^{\circ} 1.10 \mathrm{ml}$ of appropriate solution was added to each Petri dish (Asgharipour and Rafiei, 2011). Seeds were imbibed in $\mathrm{NaCl}$ solutions for $24 \mathrm{H}$ at room temperature. Seeds were then drained, rinsed twice with distilled water, and were allowed to continue germination on new moist double-layer Whatman paper. The seed counting process started 24 hours after seeds were moistened for the first time. That process was repeated every day at the same hour. After sowing every day, the germinated seeds were counted, recorded and removed from the Petri dishes. Germination was counted when a $5-\mathrm{mm}$ radicle had emerged from the seed coat (Sayar et al., 2010). The study was concluded after 21 days.

\section{Variables studied}

Germination percentage (GP)

The number of germinated seeds was recorded every $24 \mathrm{~h}$ (AOSA, 1990). After 21 days, the germination percentage (GP) was obtained by dividing the number of germinated seeds in any Petri dishes by the total number of seeds tested, multiplied by 100 (Cokkizgin and Cokkizgin, 2010; Tanveer et al., 2010) as described below

$$
G P=\frac{\text { Total number of germinated seeds }}{\text { Total number of seeds tested }} \times 100
$$

\section{Mean germination time (MGT)}

The mean germination time (MGT) was calculated to assess the rate of germination (Hu et al., 2005) as follows:

$$
M G T=\frac{\sum T_{i} N_{i}}{\sum N_{i}}
$$

Were $\mathrm{Ni}=$ number of the newly germinated seeds in times of Ti (day)

\section{Time to $50 \%$ germination $\left(\mathrm{T}_{50}\right)$}

This is the time at the end of which $50 \%$ of the tested seeds have germinated (Côme et al., 1970). It was calculated using this formula below:

With:

$$
T_{50}=T_{1}+\frac{\left(0.5-\mathrm{G}_{1}\right)}{\left(\mathrm{G}_{2}-\mathrm{G}_{1}\right)} \times\left(T_{2}-T_{1}\right)
$$

$\mathrm{G}_{1}=$ cumulative percentage of germinated seeds whose value is closest to $50 \%$ by lower value.

$\mathrm{G}_{2}=$ cumulative percentage of germinated seeds whose value is closest to $50 \%$ by higher value.

$\mathrm{T}_{1}=$ time whose cumulative percentage of germinated seeds is closer to $50 \%$ by lower value.

$\mathrm{T}_{2}=$ time whose cumulative percentage of germinated seeds is closer to $50 \%$ by higher value.

\section{Germination index (GI)}

Germination Index (GI) was calculated as described by the Association of Official Seed Analysts (AOSA, 1983):

$$
\begin{aligned}
& G I=\sum\left(\frac{G_{t}}{T_{t}}\right)=\frac{G . \text { first count }}{\text { Days to first count }}+\cdots+ \\
& \quad \text { G. last count } \\
& \text { days to last count } \\
& \text { With } G=\text { Number of germinated seeds }
\end{aligned}
$$

\section{Coefficient of velocity of germination (CVG)}

Coefficient of velocity of germination (CVG) was evaluated according to Maguire (1962) as follows:

$$
C V G=\frac{G_{1}+G_{2}+\cdots+G_{n}}{1 \times G_{1}+2 \times G_{2}+\cdots+n \times G_{n}}
$$

Where $G$ is the number of germinated seeds and $n$ is the last day of germination.

\section{Salt tolerance index (STI)}

Salt tolerance index (STI) was calculated as according to Zeng et al., (2002)

$$
S T I=\frac{\text { Germination under salinity }}{\text { Germination in control }}
$$

\section{Statistical analysis}

Data of the germination percentage, germination index, mean germination time, time to $50 \%$ germination and the coefficient of velocity of germination were analyzed using XLSTAT 2014 and GraphPad Pism 6.0 softwares packages. Analysis of variance (ANOVA) was conducted to test the significance of differences among salinity treatment, among accessions and their interaction. Differences were declared very significant at $P<$ 0.001 and significant $P<0.01$ probability levels by 
the $F$ test. Pearson correlation coefficients were used to assess all the germinations variables under salinity. Relationships between $\mathrm{NaCl}$ concentrations and germination percentage, germination index, mean germination time, time to $50 \%$ germination and the coefficient of velocity of germination data of the genotypes were performed using $r^{2}$ goodness-of-fits of the linear regression from GraphPad Prism 6.0 computer program

\section{Results}

This study revealed a significant effect of salinity on germination traits of cowpea genotypes (Table 1). The germination percentage under control conditions fluctuated from 39 (NO193) to 100\% (OU100; OU59A and ICV12). Under salinity stress at $100 \mathrm{mM}$ and $200 \mathrm{mM} \mathrm{NaCl}$, the germination percentage ranges from 1.00 (NO193) to 98.33 (ICV12) and 0.00 (NO193) to 68.33 (ICV12) respectively. As the $\mathrm{NaCl}$ concentration increased, all the ten cowpea genotypes showed a decreasing trend of germination percentage (Figure 1A). For example, the germination percentage for the genotype NO1036 at 0,50,100, 150 and $200 \mathrm{mM}$ $\mathrm{NaCl}$ treatment were 94, 94, 88, 44 and $2 \%$ respectively. This shows that salinity stress unfavorably affected the germination of cowpea cultivars. Though the germination of cowpea seeds was strongly inhibited when subjected to salinity stress, the degree of inhibition differed markedly between genotypes. The ten genotypes studied here could be classified into three groups depending on their ability to germinate in saline medium. The most salt tolerant genotypes with the smallest degree of salt inhibition. These genotypes (OU59A, OU100, ICV12 and KEB-CP118) had higher salinity tolerance index: $>0.8$ at $150 \mathrm{mM} \mathrm{NaCl}$ and still had a STI more the 0.6 at the highest salinity condition (200mM NaCl) (Table 1). Four genotypes were found to be moderately tolerant (ET11, NO1036, MTA22 and KEB-CP009) with their STI more than 0.8 at $100 \mathrm{mM} \mathrm{Nacl}$ and less than 0.5 at $200 \mathrm{mM}$ $\mathrm{NaCl}$ (Table 1). The least tolerant (susceptible genotypes) were $N 0193$ and KEB-CP098. This group had a STI less than 0.5 at $100 \mathrm{mM} \mathrm{NaCl}$ and STI $=0$ at $200 \mathrm{mM} \mathrm{NaCl}$ (Table 1). A two-way Analysis of Variance showed a significant individual effect of salinity, genotype and their interaction in affecting germination variables in cultivated $V$. unguiculata (Table 3). The germination index (GI) and the coefficient of velocity of germination (CVG) had the same change trend with that of germination percentage (Table 1). The highest GI (16.66) and CVG (0.53) were observed in the control and the lowest values were observed at $200 \mathrm{mM} \mathrm{NaCl}$ treatment (1.63 for GI and 0.11 for CVG)). Fig. $1 \mathrm{~B}$ and $1 \mathrm{E}$ shows the change in GI and CVG respectively with different $\mathrm{NaCl}$ osmotic potentials. The different levels of $\mathrm{NaCl}$ also significantly affected the mean germination time (MGT) and time to $50 \%$ germination $\left(\mathrm{T}_{50}\right)$ (Table
1, Table 2 and Table 3). For all genotypes, significant greater number of days for MGT (5.11) and $\mathrm{T}_{50}$ (14.87) was obtained from treatments in $200 \mathrm{mM} \mathrm{NaCl}$ as compared with controls (MGT = 2.33 days and $\mathrm{T}_{50}=2.83$ days) (Table 2). Fig. 1C and $1 \mathrm{D}$ shows the variation of MGT and T50 as affected by $\mathrm{NaCl}$ osmotic potentials of cowpea seeds. The interaction between salinity level and genotypes were significant for all the germination parameters studied (Table 3). Significant positive and negative Pearson correlations were found between all the germination variables studied (Table 4).

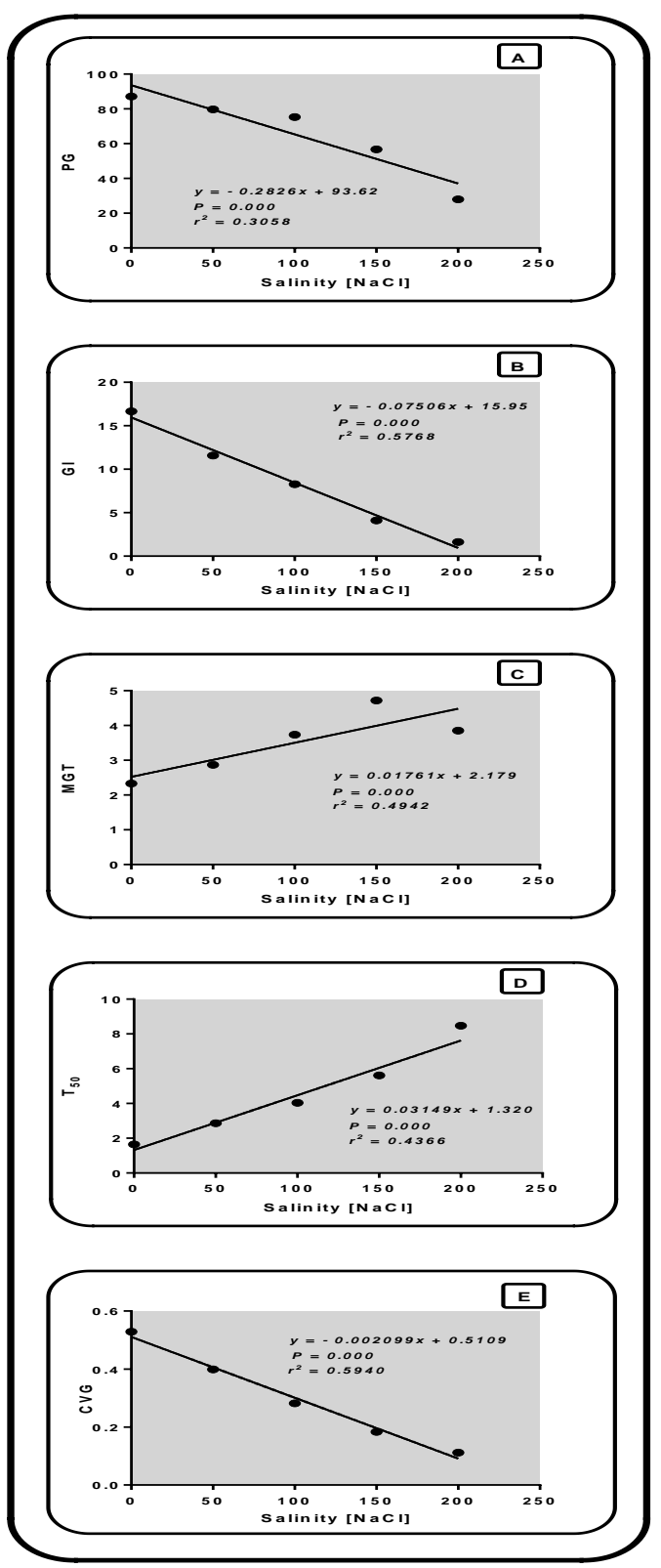

Figure 1: Relationship between germination percentage (GP), germination index (GI), mean germination time (MGT), time to $50 \%$ germination (T50), coefficient of velocity of germination (CVG) and salinity $(\mathrm{NaCl})$ level in Vigna unguiculata seeds. 
Table 1: Effects of different salinity levels on Germination percentage, Germination index, Mean germination time, Time of 50\% germination, Coefficient of velocity of germination and the Salt tolerance index of some cowpea genotypes

\begin{tabular}{|c|c|c|c|c|c|c|c|c|c|c|c|}
\hline \multirow{2}{*}{ Parameter } & \multirow{2}{*}{ Salinity } & \multicolumn{10}{|c|}{ Genotype } \\
\hline & & ET11 & NO1036 & NO193 & KEB-CP118 & MTA22 & OU100 & KEB-CP098 & KEB-CP009 & OU59A & ICV12 \\
\hline \multirow{5}{*}{ PG } & $0 \mathrm{mM}$ & 59.00 & 94.00 & 39.00 & 100.00 & 92.00 & 100.00 & 97.67 & 98.33 & 100.00 & 100.00 \\
\hline & $50 \mathrm{mM}$ & 52.00 & 94.00 & 4.00 & 98.57 & 92.00 & 100.00 & 68.33 & 91.67 & 100.00 & 98.33 \\
\hline & $100 \mathrm{mM}$ & 51.00 & 88.00 & 1.00 & 97.14 & 86.00 & 98.00 & 38.33 & 86.67 & 98.00 & 98.33 \\
\hline & $150 \mathrm{mM}$ & 12.00 & 44.00 & 0.00 & 95.71 & 74.00 & 86.00 & 15.00 & 68.33 & 80.00 & 91.67 \\
\hline & $200 \mathrm{mM}$ & 0.00 & 2.00 & 0.00 & 71.43 & 32.00 & 32.00 & 0.00 & 10.00 & 64.00 & 68.33 \\
\hline \multirow{5}{*}{ GI } & $0 \mathrm{mM}$ & 13.53 & 11.71 & 3.89 & 21.33 & 13.13 & 17.50 & 21.91 & 26.67 & 17.79 & 19.17 \\
\hline & $50 \mathrm{mM}$ & 9.61 & 8.44 & 0.44 & 17.25 & 11.56 & 13.50 & 6.21 & 20.85 & 12.92 & 14.92 \\
\hline & $100 \mathrm{mM}$ & 7.32 & 4.45 & 0.05 & 14.92 & 8.99 & 10.64 & 2.06 & 13.71 & 8.73 & 11.81 \\
\hline & $150 \mathrm{mM}$ & 1.30 & 1.66 & 0.00 & 10.43 & 4.24 & 4.87 & 0.66 & 7.06 & 4.28 & 6.66 \\
\hline & $200 \mathrm{mM}$ & 0.00 & 0.06 & 0.00 & 4.58 & 1.41 & 1.37 & 0.00 & 0.54 & 4.78 & 3.52 \\
\hline \multirow{5}{*}{ MGT } & $0 \mathrm{mM}$ & 3.37 & 2.19 & 6.29 & 1.77 & 1.86 & 1.64 & 1.62 & 1.20 & 1.62 & 1.73 \\
\hline & $50 \mathrm{mM}$ & 3.74 & 3.22 & 4.83 & 2.16 & 2.24 & 1.98 & 4.71 & 1.62 & 2.12 & 2.07 \\
\hline & $100 \mathrm{mM}$ & 3.80 & 5.58 & 5.00 & 2.51 & 3.22 & 2.70 & 6.05 & 2.41 & 3.31 & 2.76 \\
\hline & $150 \mathrm{mM}$ & 5.38 & 6.82 & / & 3.93 & 5.15 & 5.19 & 7.00 & 3.22 & 5.72 & 4.81 \\
\hline & $200 \mathrm{mM}$ & / & 4.00 & / & 6.12 & 5.76 & 5.9 & / & 6.13 & 4.60 & 6.03 \\
\hline \multirow{5}{*}{ T50 } & $0 \mathrm{mM}$ & 5.28 & 1.52 & 13.54 & 1.34 & 1.51 & 1.13 & 0.96 & 0.63 & 1.12 & 1.3 \\
\hline & $50 \mathrm{mM}$ & 8.95 & 2.56 & / & 1.60 & 1.71 & 1.49 & 5.25 & 1.03 & 1.62 & 1.55 \\
\hline & $100 \mathrm{mM}$ & 7.75 & 5.23 & / & 1.81 & 2.41 & 2.04 & 11.19 & 1.75 & 2.54 & 1.94 \\
\hline & $150 \mathrm{mM}$ & 35.94 & 10.21 & / & 3.22 & 6.06 & 5.21 & 38.57 & 4.06 & 6.00 & 4.55 \\
\hline & $200 \mathrm{mM}$ & / & / & / & 6.6 & 10.91 & 11.25 & / & 46.87 & 7.00 & 6.60 \\
\hline \multirow{5}{*}{ CVG } & $0 \mathrm{mM}$ & 0.30 & 0.46 & 0.16 & 0.57 & 0.54 & 0.61 & 0.62 & 0.83 & 0.62 & 0.58 \\
\hline & $50 \mathrm{mM}$ & 0.27 & 0.31 & 0.21 & 0.46 & 0.45 & 0.51 & 0.21 & 0.62 & 0.47 & 0.48 \\
\hline & $100 \mathrm{mM}$ & 0.26 & 0.18 & 0.05 & 0.39 & 0.32 & 0.37 & 0.17 & 0.42 & 0.30 & 0.36 \\
\hline & $150 \mathrm{mM}$ & 0.19 & 0.15 & 0.00 & 0.26 & 0.20 & 0.19 & 0.14 & 0.31 & 0.18 & 0.21 \\
\hline & $200 \mathrm{mM}$ & 0.00 & 0.06 & 0.00 & 0.16 & 0.17 & 0.17 & 0.00 & 0.16 & 0.23 & 0.17 \\
\hline \multirow{4}{*}{ STI } & $50 \mathrm{mM}$ & 0.88 & 1.00 & 0.10 & 0.98 & 1.00 & 1.00 & 0.70 & 0.93 & 1.00 & 0.98 \\
\hline & $100 \mathrm{mM}$ & 0.86 & 0.93 & 0.03 & 0.97 & 0.93 & 0.98 & 0.39 & 0.88 & 0.98 & 0.98 \\
\hline & $150 \mathrm{mM}$ & 0.20 & 0.47 & 0.00 & 0.95 & 0.80 & 0.86 & 0.15 & 0.69 & 0.80 & 0.92 \\
\hline & $200 \mathrm{mM}$ & 0.00 & 0.21 & 0.00 & 0.71 & 0.35 & 0.32 & 0.00 & 0.10 & 0.64 & 0.68 \\
\hline
\end{tabular}

Table 2: Salinity effects on germination parameters in cowpea (Vigna unguiculata)

\begin{tabular}{llllll}
\hline \multirow{2}{*}{ Salinity level (NaCl) } & \multicolumn{5}{c}{ Germination parametres } \\
\cline { 2 - 6 } & \multicolumn{1}{c}{ GP (\%) } & \multicolumn{1}{c}{ GI } & MGT (Days) & T $_{50}$ (Days) & CVG \\
\hline $0 \mathrm{mM}$ & $88.00 \pm 6.73^{\mathrm{a}}$ & $16.66 \pm 2.01^{\mathrm{a}}$ & $2.33 \pm 0.47^{\mathrm{c}}$ & $2.83 \pm 1.26^{\mathrm{b}}$ & $0.53 \pm 0.06^{\mathrm{a}}$ \\
$50 \mathrm{mM}$ & $79.89 \pm 9.81^{\mathrm{a}}$ & $11.57 \pm 1.83^{\mathrm{b}}$ & $2.87 \pm 0.37 \mathrm{bc}$ & $2.86 \pm 0.87 \mathrm{~b}$ & $0.40 \pm 0.04^{\mathrm{b}}$ \\
$100 \mathrm{mM}$ & $74.25 \pm 10.49^{\mathrm{ab}}$ & $8.27 \pm 1.54^{\mathrm{c}}$ & $3.73 \pm 0.42^{\mathrm{b}}$ & $4.07 \pm 1.12^{\mathrm{b}}$ & $0.28 \pm 0,03^{\mathrm{c}}$ \\
$150 \mathrm{mM}$ & $56.67 \pm 11.40^{\mathrm{b}}$ & $4.12 \pm 1.05^{\mathrm{d}}$ & $5.24 \pm 0.40^{\mathrm{a}}$ & $12.65 \pm 4.70^{\mathrm{a}}$ & $0.18 \pm 0.02^{\mathrm{d}}$ \\
$200 \mathrm{mM}$ & $27.98 \pm 9.54^{\mathrm{c}}$ & $1.63 \pm 0.61^{\mathrm{e}}$ & $5.51 \pm 0.32^{\mathrm{a}}$ & $14.87 \pm 6.45^{\mathrm{a}}$ & $0.11 \pm 0.03^{\mathrm{d}}$ \\
\hline
\end{tabular}

Means followed by the same letter in the same column are not significantly different at $\mathrm{p}=0.050$ probability level

Table 3: Summary of analysis of variance of genotypes, salinity and genotype - salinity interaction for all the analyzed germination parameters

\begin{tabular}{|c|c|c|c|c|c|c|c|}
\hline \multirow[b]{2}{*}{ Source of Variation } & \multirow{2}{*}{ df } & & \multicolumn{5}{|c|}{ Germination parameters } \\
\hline & & & PG & GI & MGT & $\mathbf{T}_{50}$ & CVG \\
\hline \multirow{4}{*}{ Genotype } & & MS & 15549.52 & 319.59 & 3.15 & 8224.36 & 0.25 \\
\hline & 9 & $\mathrm{~F}$ & 334.9 & 315.05 & 2.67 & 178.56 & 441.13 \\
\hline & & $P$ value & 0.000 & 0.000 & 0.007 & 0.000 & 0.000 \\
\hline & & MS & 22467.76 & 1425.61 & 34.36 & 4262.66 & 1.11 \\
\hline \multirow[t]{3}{*}{ Salinity } & 4 & $\mathrm{~F}$ & 483.91 & 1405.33 & 29.17 & 92.55 & 1965.59 \\
\hline & & $P$ value & 0.000 & 0.000 & 0.000 & 0.000 & 0.000 \\
\hline & & MS & 862.15 & 33.01 & 16.28 & 2732.25 & 0.02 \\
\hline \multirow[t]{2}{*}{ Genotype X Salinity } & 36 & $\mathrm{~F}$ & 18.57 & 32.53 & 13.82 & 59.32 & 35.29 \\
\hline & & $P$ value & 0.000 & 0.000 & 0.000 & 0.000 & 0.000 \\
\hline
\end{tabular}

Table 4: Summary of Pearson's correlation coefficients between the analyzed germination parameters

\begin{tabular}{|c|c|c|c|c|c|}
\hline & GP & IG & MGT & $\mathbf{T}_{50}$ & CVG \\
\hline PG & 1.000 & & & & \\
\hline IG & $0.792 * * *$ & 1.000 & & & \\
\hline MGT & $-0.695^{* * *}$ & $-0.894 * * *$ & 1.000 & & \\
\hline $\mathrm{T}_{50}$ & $-0.845^{* * *}$ & $-0.597 * *$ & $0.628^{* * *}$ & 1.000 & \\
\hline CVG & $0.774 * * *$ & $0.955^{* * *}$ & $-0.896 * * *$ & $-0.520 * *$ & 1.000 \\
\hline
\end{tabular}

Discussion

From the economical point of view, screening crops for salinity tolerance is of great importance for better utilization of zones affected by salt. To explore salt tolerance of 10 genotypes of cultivated Vigna unguiculata at the germination stage, four level of salt stress and a control was examined in this study. The experiment revealed that salt stress induced lower germination percentage, germination index and coefficient of velocity of germination and increased time for germination (Mean germination 
time and time to $50 \%$ germination) of the ten genotypes seeds (Tables 1, Table2, Table 3 and Figure 1). For example, four genotypes (ET11, NO1036, NO193 and KEB-CP098) at $200 \mathrm{mM} \mathrm{NaCl}$ had less than $2 \%$ of germinated seeds with their germination indices closes to zero (Table 1). These results indicate that the germination of some genotypes is completely inhibited under high salinity conditions. Similar results were highlighted in Phaseolus species (Alihan, 2012; Eroglu, 2007; Bayuelos et al., 2002) and Crithmum species (Duros and Magne, 2008). A significant and negative slope was established in the relationship between data for germination index and $\mathrm{NaCl}$ concentration (Figure 1B). The higher the $\mathrm{NaCl}$ concentration, the lower the germination index of cowpea genotypes (Table 2, Figure 1B). The decrease in ability of cowpea seeds to germinate under salinity conditions is likely due to a reversible osmotic effect that induced dormancy by saline stress (Mehrun-Nisa et al., 2007).

Germination time in cowpea seeds was considerably affected by salinity. The different levels of $\mathrm{NaCl}$ significantly affected the mean germination time (MGT) and time to 50\% germination $\left(T_{50}\right)$ (Table 1$)$. Significant greater number of days for MGT and $\mathrm{T}_{50}$ for all genotypes was obtained from treatments in $200 \mathrm{mM} \mathrm{NaCl}$. Fig. $1 \mathrm{~B}$ and $1 \mathrm{C}$ shows the relationship between the MGT, $\mathrm{T}_{50}$ and $\mathrm{NaCl}$ osmotic potentials of cowpea seeds through regression analysis with slopes of these two regressions statistically different from zero. As the increase in salinity decrease the germination, it also delays the germination initiation as MGT and $\mathrm{T}_{50}$ increase with the salinity (Hajer et al., 1996). These delay or inhibition in germination under salt stress is due to osmotic effect limiting uptake of water during seed germination (Flowers, 1986; El-Baz et al., 2003). Karagiizel (2003) reported that germination time in several plant species considerably increases with an increase in salt concentration. This delay in seed germination or prolongation of germination time of the genotypes studied has also been observed in oryza species by Hakim et al., (2011) and Limonium species (Redondo-Gomez et al., (2008) who detected the increase in MGT with the increase in $\mathrm{NACl}$ osmotic potentials. The extension of time to $50 \%$ germination observed in this study also fits the conclusion of Mrani et al., (2013) on Moroccan wheat varieties.

\section{Conclusion}

Considerable variations in salt tolerance were found among the studied cowpea genotypes at the germination level. The relationship between germination variables and $\mathrm{NaCl}$ osmotic potentials through regression analysis were significantly different from zero at 0.001 probability level. The percentage of germination (PG), germination index
(GI) and the coefficient of velocity of germination (CVG) decreased significantly with increasing salinity while the mean time of germination (MGT) and time to $50 \%$ germination $\left(T_{50}\right)$ (Figure 1 ) increased significantly with increasing salinity. Positive significant correlations were found between Germination percentage and Germination index $(r=0.792)$ and Coefficient of velocity of germination $(r=0.774)$. Negative significant correlation were observed between germination percentage and Mean germination time $(r=-0.695)$ and time to $50 \%$ germination $(\mathrm{r}=-0.845)$ ). According to the results, genotypes OU59A, ICV12, KEB-CP118 and OU100 were identified as tolerant; ET11, NO1036, MTA22 and KEB-CP009 were considered as moderately tolerant. The two other genotypes (N0193 and KEB-CP098) were susceptible to salt stress. Further study will be necessary to assess whether these genotypes characterized at the germination level as tolerant based on their responses to salt stress maintains their tolerance at other growth and maturity stages.

\section{References}

1. Akibode CS, Trends in the production, trade, and consumption of food-legume crops in sub- Saharan Africa. Master thesis, Michigan State University; 2011. 85p

2. Alihan C, Salinity Stress in Common Bean (Phaseolus vulgaris L.) Seed Germination, Not Bot Horti Agrobo, 2012, 40, 177-182.

3. Asana RD, Kale VR, A study on salt tolerance of four wheat varieties. Ind J Plant physiol, 1965, 8, 5- 22.

4. Asgharipour MR, Rafiei M, Effect of salinity on germination and seedling growth of lentils, Austr J Basic Appl Sci, 2011, 5, 2002-2004.

5. Association of Official Seed Analysts (AOSA), Rules for Testing Seeds. J Seed Technol, 1990, 12,1-112.

6. Association of Official Seed Analysts (AOSA), Seed Vigor Hand Testing Book, Contribution No. 32 to the Handbook on Seed esting, Association of Official Seed Analysts, Springfield, USA, 1983, 122-128.

7. Bayuelos J, Craig R, Lynch J, Salinity tolerance of Phaseolus species during germination and early seedling growth, Crop Sci, 2002, 42,1584-1594.

8. Chinma CE, Alemede IC, Emelife IG, Physicochemical and functional properties of some Nigerian cowpea varieties, Pakistan Journal of Nutrition, 2008, 7, 186-190.

9. Cokkizgin $\mathrm{A}$, Cokkizgin $\mathrm{H}$, Effects of lead $\left(\mathrm{PbCl}_{2}\right)$ stress on germination of lentil (Lens culinaris Medic.) lines, Afr J Biotechnol, 2010, 9, 8608-8612.

10. Côme D, Les obstacles à la germination, Masson et Cie, Paris, 1970, 162p.

11. Dantas BF, De Sa Ribeiro L, Aragao CA, Germination, initial growth and cotyledon protein content of bean cultivars under salinity stress, Rev Bras de Sementes, 2007, 29,106-110.

12. Duros LM, Magne C, Effect of salinity and chemical factors on seed germination in the halophyte Crithmum maritimum L., Plant and Soil, 2008, 313, 83-87. 
13. El-Baz F, Mohamad AA, Aly AA, Development of biochemical markers for salt stress tolerance in cucumber plants, Pak J Biol Sci, 2003, 6, 16-22.

14. Eroglu I, Effects of salt stress on the seed germination and seedling growth of some bean (Phaseolus vulgaris L.) Cultivars. Ege University Graduate School of Natural and Applied Sciences, PhD Thesis 2007, 77p.

15. Flowers TJ, Flower SA, Greenway HC, Effect of Sodium chloride on Tobacco plants, Plant cell Environ, 1986, 9, 645-651.

16. Hajar AS, Zidan MA, Sahruni HA, Effect of $\mathrm{NaCl}$ stress on germination, growth activities of black cumim (Nigella sativa L.), Arab Gulf J Sci Res, 1996, 14, 445-454.

17. Hakim MA, Juraimi AS, Hanafi MM, Selamat A, Ismail MR, Karim SM, Studies on seed germination and growth in weed species of rice field under salinity stress. J Environ Biol, 2011, 32, 529-536.

18. Hu J, Zhu ZY, Song WJ, Wang JC, Hu WM, Effects of sand priming on germination and field performance in direct-sown rice (Oryza sativa L.), Seed Sci Technol 2005, $33,243-248$

19. Karagiizel O, Effect of different salt concentrations on germination of Lupinus varius from South Anatolia, Akdeniz Universitesi Ziraat Fakultesi Dergisi, 2003, 16, 211-220.

20. Langyintuo AS, Lowenberg-DeBoer J, Faye M, Lambert D, Ibro G, Moussa B, Kergna A, Kushwaha S, Musa S Ntoukam G, Cowpea supply and demand in West and Central Africa. Field Crops Research 2003, 82, 215-231.

21. Maas EV, Hoffman GJ, Crop salt tolerance, current assessment. J Irrig Drain Div ASCE, 1977, 103, 115-134.

22. Maguire JD, Speed of germination-aid in selection and evaluation for seedling emergence and vigor, Crop Sci, 1962, 2, 176-177.

23. Mahamadou T, Antony C, Diaga D, Mame OSY, $\mathrm{NaCl}$ Effects on In Vitro Germination and Growth of Some Senegalese Cowpea (Vigna unguiculata (L.) Walp.) Cultivars, ISRN Biotechnology, 2013, 11p.

24. Mehrun N, Khan MA, Weber DJ, Dormancy, germination and viability of Salsola imbricate seeds in relation to light temperature and salinity, Seed Sci Technol, 2007, 35, 595606.

25. Mrani Alaoui M, El Jourmi L, Ouarzane A, Lazar1 S, El Antri1 S, Zahouily M, Hmyene A, Effect of salt stress on germination and growth of six Moroccan wheat varieties, J Mater Environ Sci, 2013, 4, 997-1004

26. Munns R, Tester M, Mechanisms of salinity tolerance. Annual Review of Plant Biology 2008, 59, 651-681.

27. Munns R, Comparative physiology of salt and water stress, Plant Cell Environ, 2002, 25, 239 -250.
28. Munns R, Physiological processes limiting plant growth in saline soils: Some dogmas and hypotheses, Plant Cell Environ, 1993, 16, 15-24.

29. Redondo-Gomez S, Mateos NE, Garzon O, Castillo JM, Luque T, Figueroa ME, Effects of salinity on germination and seedling establishment of endangered Limonium emarginatum (Willd.) O. Kuntze, J Coastal Res, 2008, 24, 201-205.

30. Rengasamy $\mathrm{P}$, Transient salinity and sub soil constraints to dry land farming in Australian sodic soils: an overview, Australian Journal of Experimental Agriculture 2002, 42, 351-361.

31. Sauer DB, Burroughs R, Disinfection of seed surfaces with sodium hypochlorite, Phytopathology, 1986, 76, 745-749.

32. Sayar R, Bchini H, Mosbahi M, Khemira H, Response of durum wheat (Triticum durum Desf.) growth to salt and drought stresses, Czech J Genet Plant Breed, 2010, 46, 54 63

33. Tanveer A, Rehman A, Javaid MM, Abbas RN, Sibtain M, Ahmad A, Zamir MS, Chaudhary KM, Aziz A, Allelopathic potential of Euphorbia helioscopia L. against wheat (Triticum aestivum L.), chickpea (Cicer arietinum L.) and lentil (Lens culinaris Medic.), Turk J Agric For, 2010, $34,75-81$.

34. Tawfik KM, Evaluating the use of rhizobacterin on cowpea plants grown under salt stress, Research Journal of Agriculture and Biological Sciences, 2008, 4, 26-33.

35. Tengomo NS, Techniques de conservation des légumineuses et sécurisation de la production des paysans: cas du niébé dans le département du Diamare. Mémoire de Master, Institut Supérieure de Sahel, Université de Maroua, 2011, 142p

36. Timko MP, Ehlers JD, Roberts PA, Cowpea In: Kole C, editor, Pulses, Sugar and Tuber Crops, Genome Mapping and Molecular Breeding in Plants, 2007, 3, 49-67.

37. Yadav SS, McNeil DL, Redden R, Patil SA, Climate change and management of cool season grain legume crops, Springer, Dordrecht; Heidelberg, 2010, 460p.

38. Yamaguchi T, Blumwald E, Developing salt-tolerant crop plants: challenges and opportunities, Trends Plant Sci, 2005, 10, 615-620.

39. Zeng I, Shannon MC, Grieve CM, Evaluation of Salt Tolerance in Rice Genotypes by Multiple Agronomic Parameters, Euphytica, 2002, 127, 235-245.

\section{Cite this article as:}

Ebeny Leonny Tsague, Eric Bertrand Kouam, Christopher Mubeteneh Tankou. Salinity tolerance at germination of some main cultivated cowpea (Vigna unguiculata) genotypes from Western Cameroon. Annals of Plant Sciences 6.6 (2017) pp. 1634-1639.

DOI : http://dx.doi.org/10.21746/aps.2017.06.002 